\title{
How Traditional Healers of Tchaoudjo District in Togo Take Care of Animal Injuries?
}

\begin{abstract}
The study aims at gathering information on plants used by traditional healers of the prefecture of Tchaoudjo located in the central region of Togo. Moreover, the perception of victims was also evaluated. Ethnobotanical semi-structured individual interviews were carried among 20 traditional healers treating animals' aggression (AA) and 16 victims of AA. Results showed that snakebites and bite from dogs are the most recurrent animals' aggression. Altogether, 32 plant species belonging to 31 genera and 22 families used in folk medicine in the treatment of AA were reported. Fabaceae (4 species) is the most represented family. Securidaca longepedunculata Fresen., Xylopia aethiopica (Dunal) A.Rich., Annona senegalensis Pers. ssp. senegalensis, and Trichilia emetica Vahl are the most reported species with respective frequencies of $90 \%, 70 \%$, $50 \%$, and $30 \%$. The root is the most exploited plant part in remedies. The oral and the cutaneous are the only way of administration. The decoction and the powder are the most reported mode of preparation. All victims interviewed confirmed the effectiveness of these plants in the traditional treatment of animal aggression $(100 \%)$. Even though remedies seem efficiency, the exploitation of roots remains a crucial threat for plant species survival.
\end{abstract}

Keywords: Ethnobotany; Medicinal plants; Animal aggression; Tchaoudjo; Togo

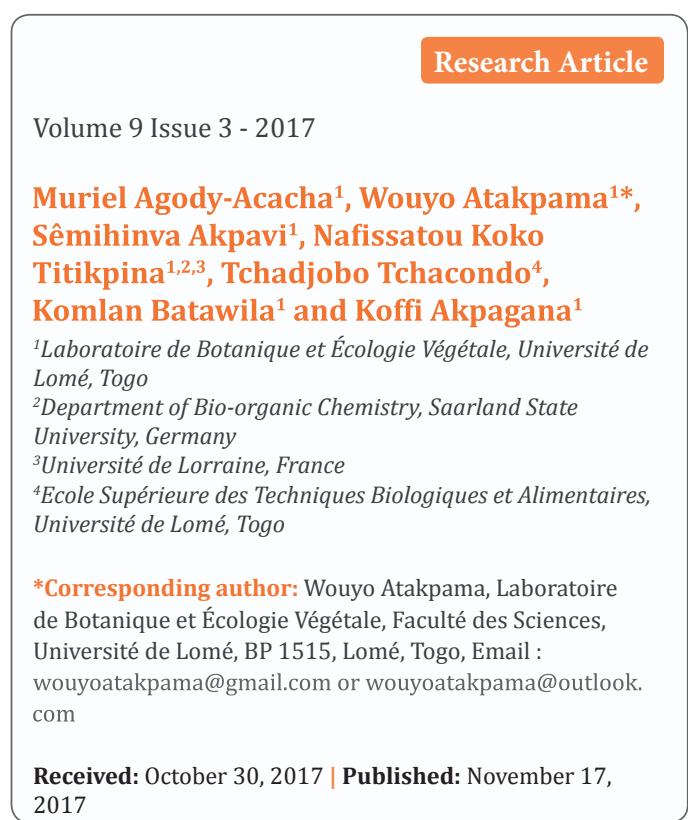

\section{Introduction}

There is a lot of aggression that people can undergo from animals. They can be scratched, bitten, stung, scratched or devoured by an animal. However, the most alarming animal injuries are bites and stings. In Africa, houses and vegetation are sometime closely spaced. Thus, people are substantially exposed to animal aggression. Epidemiological studies done in hospitals and clinics of several African countries confirmed that animal aggression, especially bites and stings are frequent in tropical and subtropical regions.

The world yearly number of snakebites exceeds 5 million while scorpion stings were estimated about 1.2 million [1-3]. The yearly incidence of snakebites was estimated about 915 bites for 100000 inhabitants in Bandafasi in Senegal, 375 in Guinée, 486 in Benin [4-6]. Regardless scorpion stings, at least 50000 cases were reported per year in Algeria [7], and 44 cases were counted in paediatric service for six (6) months at Agadez in Niger [8].

In Togo, APANews [9] reported from 2006 to 2009, eight thousand people bitten by dogs. Additional study from 2009 to 2010 on hospital admission due to animals' bites showed that dogs (89\%) are the primary aggressive animals in Lomé [10]. Most of five (5) thousands cases of snakebite are yearly registered officially in hospital in Togo [11]. These numbers are underestimated, since there is a lack of reliable and recent statistic data. Most of surveys were achieved in hospital, since after a bite or stings most of people were cured traditionally due the non- proximity of hospitals and the living standards. Some of victims live in rural communities and visit in priority traditional healers [5]. So, the majority are treated by folk medicine [12]. Therefore, it is necessary to assess the importance of folk medicine healing in animal aggression.

In what manner animal aggression are treated in traditional medicine? Which plant species are used for these purposes? The present study is a contribution to the valorization of traditional medicine in Togo. It aims to: (i) inventory medicinal plants used in the treatment of animal aggression by traditional healers (TH) in the central region of Togo, and (ii) determine modes and frequencies of use of these plants as well as victims perception about the treatment gained from TH. The choice of the study area was directed by the fact that the main ethnic group of this zone of Togo, the Tem especially was known for their involvement in traditional medicine [13].

\section{Materials and Methods}

\section{Study area}

The study was conducted in Tchaoudjo prefecture located in the Central Region of Togo (Figure 1). It population is about 190114 inhabitants with 50\% living in rural residents [14]. It is bordered by Kara, Tchamba, Sotouboua, and Bassar prefectures respectively at north, east, southwest, and northwest. The dominant vegetation is Guinean savannah woodland. Open forests of Anogeissus leiocarpus (DC) Guill. \& Perr., Pterocarpus 
erinaceus Poir, and Isoberlinia spp.. A mosaic savannah-fieldsfallow and parklands are also observed $[15,16]$. According MERF [17], all Togolese ecosystems were degraded by anthropogenic threats in recent decades. Classified forests and reserves were looted, vandalized and occupied by the human population. Animal species in these forests and reserves now live within fragmented and disturbed habitats, resulting in a significant change in their distribution. Agriculture remains the main activity of residents. As in most African countries, the population of the study area attach great importance to the healing powers of plants [13]. The main ethnic group of this region is Tem.

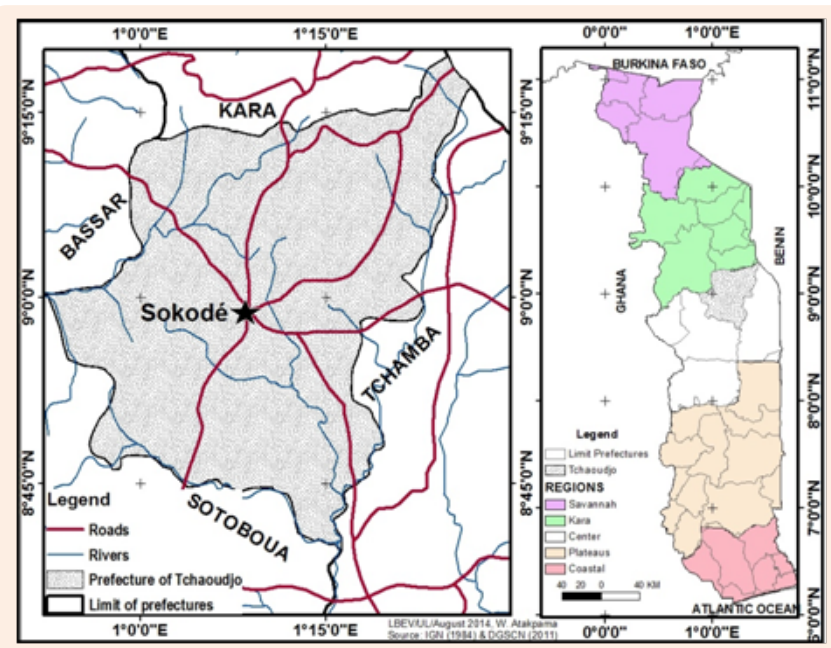

Figure 1: Localization of the prefecture of Tchaoudjo with main roads and rivers.

\section{Data Collection and analysis}

Data were collected in December 2013. The methodology followed was based on ethnobotanical semi-structured individual interviews $[18,19]$ of 20 traditional healers and 16 victims bite and/or sting by animals. The majority of informants are men with an average age of 43 years. Only two victims and one traditional healer are women. About 55.5\% are illiterate and 30.5 had attended the primary school. Beforehand interviews, informants' agreement was obtained by explaining the study aims to the head of traditional healers' association of Central Region called CERMETRA and then all traditional healers' staff. Traditional healers were called through the local radio communicate. Within these traditional healers, only those who had cured at least once an animal aggression and accepted to participate to the interviews were sampled. This sampling methodology justified the limited sample size. Moreover, traditional healers were asked to bring victims who accepted to participate.

The information sought is focused on: different types of animal aggression healed, plants used in the therapy, plant parts used, modes of preparation and administration. Especially victims were asked to value the recovery: if it is complete, half-done or not, rapid, and the secondary effects. Interviews were coupled to field observations and collection of plant species reported and victims' status. Plants nomenclature followed the one set by
Hutchinsonet al. [20] and Brunelet al. [21]. Data analysis consisted to a descriptive statistic. All data recorded during were typed and processed using Excel spreadsheet. Results were presented as histograms and table.

\section{Results}

\section{Types of animal aggression}

Five animal aggression was recorded: snakebites, bite from dogs (Canis lupus familiaris Linnaeus, 1758), bite from squirrels (Myosciurus pumilio Le Conte, 1857), bite from cats (Felis silvestris catus Linnaeus, 1758), and sting of scorpions (Hottentotta tamulus Fabricius, 1798; Androctonus spp). All victims interviewed have been bitten by a snake. Snakebites (51\%), followed by bites from dogs $(31 \%)$ are the most recurrent animal aggression cured by traditional healers. The information gathered didn't permit to identify clearly culprit snakes.

\section{Plants used in animal aggression treatments}

A total of 32 plant species distributed into 31 genera and 22 botanic families were reported (Table 1). The most represented families are Fabaceae (4 species), followed by Alliaceae, Annonaceae, Bignoniaceae, Euphorbiaceae, Myrtaceae, Sapindaceae, and Solanaceae represented by two species each. The other families were represented by only one species. The most reported species are: Securidaca longepedunculata Fresen. (90\%), Xylopia aethiopica (Dunal) A. Rich. (70\%), Annona senegalensis Pers. ssp. Senegalensis (50\%), and Trichilia emetica Vahl (30\%) (Figure 2). Species are sometimes associated: for example, $S$. longepedunculata is used together with $X$. aethiopica and $A$. senegalensis. About $45 \%$ of species are used in the treatment of snakebites and $30 \%$ in the treatment of bites from dogs (Figure $3)$. The majority of traditional healers use roots (94.44\%) in the treatment of animal aggression. They also reported fruits and leaves. Seeds and entire plants were less used (Figure 4).

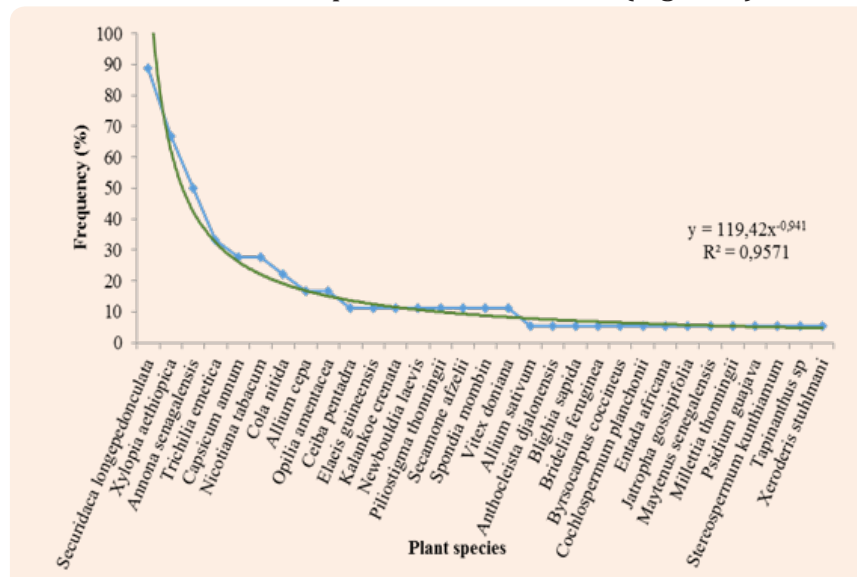

Figure 2: Frequencies rank of plant species recorded

\section{Modes of preparation and administration}

Before preparation according to a given mode, traditional healers grind and crush plant parts. The most frequent modes of preparation are the decoction and the powder (Figure 5), followed 
by the maceration and the calcination. The cooking steam is mentioned by only one informant. The decoction is a soup with like only dressing of salt. Only two types of administration were used: buccal and cutaneous. The powder is the form of conservation.

\section{Treatment perception}

The overall healers agreed that the recovery is easier and faster if victims are granted immediately after the aggression.
Most halers (75\%) received patients who did not have satisfaction with modern medicine. Their healing is complicated and long. The maximum recovery time is two weeks when the aggression is immediately cured. The follow-up of patients by healers is stopped after three days of treatment. Victims return at their own home where they pursue the treatment until the full recuperation. As for the opinion of victims, they are all satisfied with their recovery. No secondary effect related to therapy was reported.

Table 1: List of plants reported with types of animal aggression.

\begin{tabular}{|c|c|c|}
\hline Species & Families & Types of Aggression \\
\hline Afraegle paniculata (Schumach. \& Thonn.) Engl. & Rutaceae & Dog* \\
\hline Agenope stuhlmanii (Taub) Adema & Alliaceae & Snake*, dog* \\
\hline Allium cepa $\mathrm{L}$. & Alliaceae & Scorpion** \\
\hline Allium sativum L. & Annonaceae & Squirel*, snake* \\
\hline Annona senegalensis Pers. & Loganiaceae & Dog* \\
\hline Anthocleista djalonensis A. Chev. & Sapindaceae & Snake* \\
\hline Blighia sapida König & Euphorbiaceae & Snake* \\
\hline Bridelia ferruginea Benth. & Connaraceae & Dog* \\
\hline Byrsocarpus coccineus Thonn. ex Schumach. & Solanaceae & Squirrel**, snake*, dog* \\
\hline Capsicum annum L. & Bombacaceae & Snake*, dog* \\
\hline Ceiba pentadra (L.) Gaertn. & Cochlospermaceae & Snake* \\
\hline Cochlospermum planchonii Hook. f. & Sterculiaceae & Dog* \\
\hline Cola nitida (Vent.) Sebott \& Endl. & Arecaceae & Snake* \\
\hline Elaeis guineensis Jacq. & Fabaceae & Snake* \\
\hline Entada africana Gill. \& Perr. & Euphorbiaceae & Dog* \\
\hline Gymnosporia senegalensis (Lam.) Loes & Crassulaceae & Snake*, scorpion** \\
\hline Jatropha gossypifolia L. & Myrtaceae & Dog* \\
\hline Kalanchoe crenata (Andrews) Haw. & Fabaceae & Snake* \\
\hline Millettia thonningii (Schumach. \& Thonn.) Baker & Bignoniaceae & Snake*, scorpion** \\
\hline Newboudia laevis (P. Beauv.) Seemann ex Bureau & Solanaceae & Squirrel*, snake*, dog*, scorpion** \\
\hline Nicotiana tabacum L. & Opiliaceae & Snake* \\
\hline Opilia amentaceae Roxb. & Sapindaceae & Dog* et chat \\
\hline Paullinia pinnata $\mathrm{L}$. & Fabaceae & Snake*, scorpion** \\
\hline Piliostigma thoningii (Schumach.) Milne-Redh & Myrtaceae & Scorpion** \\
\hline Psidium guajava L. & Asclepiadaceae & Dog* \\
\hline Secamone afzelii K. Schum. & Polygalaceae & Snake*, squirrel* \\
\hline Securidaca longepedunculata Fresen. & Anacardiceae & Snake* \\
\hline Spondias mombin L. & Bignoniaceae & Snake* \\
\hline Stereospermum kunthianum Cham. & Loranthaceae & Dog* \\
\hline Tapinanthus sp & Meliaceae & Snake*, dog* \\
\hline Trichilia emetica Vahl. & Fabaceae & Snake* \\
\hline Xylopia aethiopica (Dunal) A. Rich. & Annonaceae & Snake*, squirrel* \\
\hline
\end{tabular}

$*=$ Bites; $^{* *}=$ Stings 


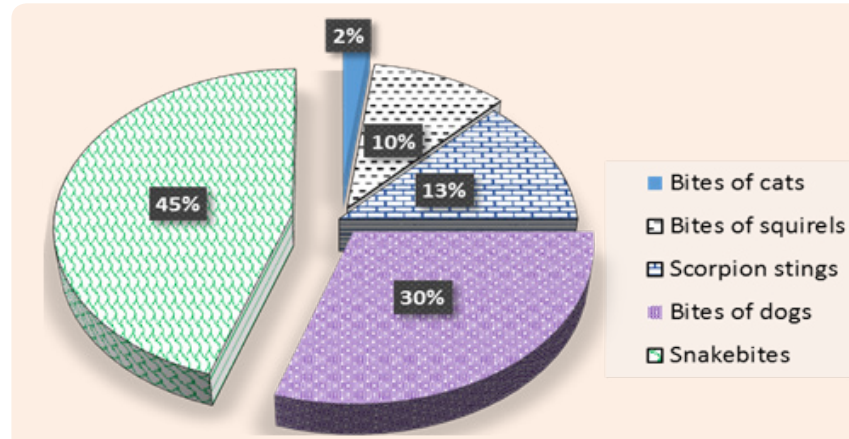

Figure 3: Repartition of species according to animal aggression.

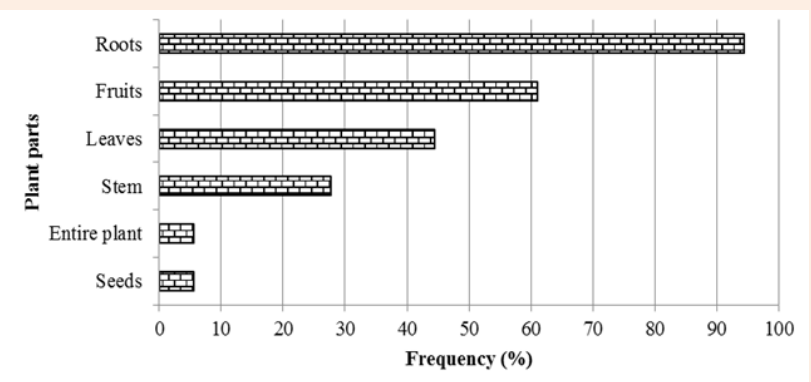

Figure 4: Frequencies of plant parts reported.

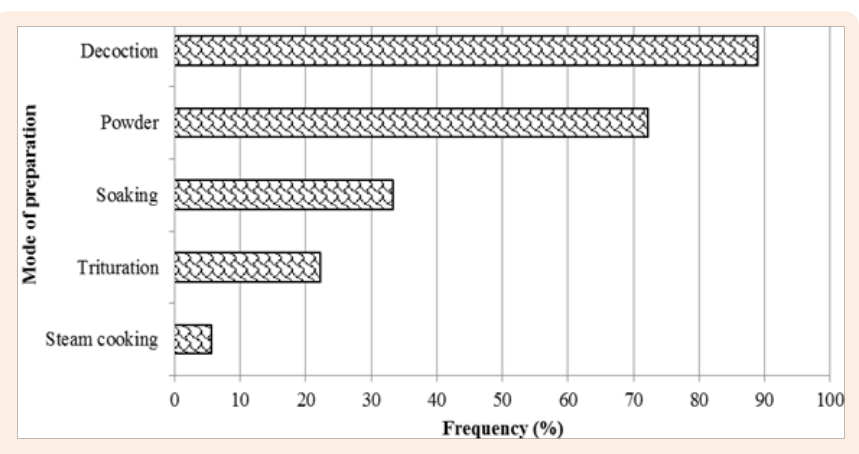

Figure 5: Frequencies of modes of preparations.

\section{Discussion}

The present study showed that snakebites, followed by bites of dogs are the prominent animal injuries in Tchaoudjo. According to Wateba et al. [10], in urban town of Lomé (Togo), the prominent animal aggression is bites of dogs. In contrast, snakebites and scorpion bites are not registered during their studies. This difference is due to the fact that bushes are scared in Lomé City by comparison to Tchoudjo prefecture where houses were embedded in bushes. Bushes are habitat of scorpions and snakes. The frequent use of $S$. longepedunculata versus snakebites is undoubtedly owed to its genuine mechanism action confirmed by the study of Chippaux [1]. Indeed, the extract of S. longepedunculata contains a systemic antidote acting by competition with the toxin contained in venom. The same authors describe $A$. senegalensis like an antivenin and a powerful therapeutic plant species used throughout Africa. The use of $A$. senegalensis and $O$. amentacea reported during this study was also mentioned by Durecu [22].
The association of $S$. longepedunculata, A. senegalensis and $X$. aethiopica in the treatment of the snake bites was previously reported by Adjanohounet al. [23] in Tgo.

According to the present results, root is nearest the used plant part in the treatment of animal aggression. The frequent use of roots in traditional medicine was also reported by previous studies done in the coastal region of Togo [24,25]. Other studies also reported the higher usage of bark [26,27]. In contrast, study concerning dietary plants species showed that leaf and fruits are the most used plant parts $[18,28]$. The harvesting of roots jeopardized plant species survival and regeneration [27,29]. Consequently, several plants become scarcer and scarcer and stake to disappear in future.

The satisfaction of victims demonstrates the effectiveness of traditional medicine against animal aggression. However, traditional healers' knowledge on hygiene and material semiotics are very limited.

The specificity of the mode of action of various medicinal plants requires some precision in the diagnostic (culprit animals, time between the injury and the treatment, symptoms presented by victims). Since the intensity of venom depends on the culprit animal species, its identification through a permanent observation and determination must be performed. In addition, the toxicity of the plant and the method of preparation must be better controlled. Indeed, the nature of the active principle determines its method of preparation.

Decoction, the most used method of preparation by $\mathrm{TH}$ consulted during fieldwork, is the process in which remedies (the plant part) is immersed in a liquid solvent (water) placed in turmoil. This is a brutal process that should be reserved for the extraction of active ingredients non thermo-labile [7]. The risk of impaired active ingredients may explain the adoption of less damaging methods of preparation by some traditional healers (maceration, crushing and steam cooking).

The ineffective treatment of victims admitted so later after the bite or sting could be linked to toxins high-speed progression in the body $[12,30]$. According to the same authors, complications can occur by necrosis and haemorrhagic syndromes and lead to respiratory failure from two (2) to ten (10) hours in the case cobra syndrome or progress to visceral complications in the case of viperine syndrome.

\section{Conclusion}

This study showed that snakebites and dog bite are the most frequently animal aggression encountered in the central region of Togo. Several plant species (32) were used to composed receipts used in folk medicine in the treatment of these aggressions. Especially S. longepedunculata, X. aethiopica, A. senegalensis and T. emetica were quoted as the most used species. A root, essential part in the existence of plants, is the most harvested plant parts. From the opinion poll, the therapy is efficient and does not induce secondary effects. However, this assertion must be verified by scientists, especially the biological action, the phytochemical analysis, the toxicity and the chrono-toxicity. It would be interesting to enlighten traditional healers about the nuisance of 
roots harvesting on species survival and availability. Collaboration between modern and traditional medicine seems unavoidable to allow the validation and the improvement of traditional remedies. A perfect complementarity between both will improve the living conditions of populations.

\section{Acknowledgements}

Our heartleaf to informants who accepted to share their knowledge freely with us. We dearly thank reviewers for their comments and suggestions.

\section{Conflict of Interest}

None.

\section{References}

1. Chippaux JP (2011) Estimate of the burden of snakebites in subSaharan Africa: A meta-analytic approach. Toxicon 57(4): 586-599.

2. Chippaux JP (2008) Estimating the global burden of snakebite can help to improve management. PLoS medicine 5(11): e221.

3. Chippaux JP, Goyffon M (2008) Epidemiology of scorpionism: a global appraisal. Acta tropica 107(2): 71-79.

4. Baldé M, Camara A, Koivogui A, Camara S (2005) Incidence des morsures de serpent: enquête communautaire dans la collectivité rurale de développement (CRD) de Frilguiagbé (République de Guinée). Bull Soc Pathol Exot 98(4): 283-284.

5. Chippaux JP (2005) Évaluation de la situation épidémiologique et des capacités de prise en charge des envenimations ophidiennes en Afrique subsaharienne francophone. Bull Soc Pathol Exot 98(4): 263-268.

6. Chippaux JP (2002) Epidémiologie des morsures de serpent au Bénin. Bull Soc Pathol Exot 95(3): 172-174.

7. Benguedda A, Laraba-Djébari F, Ouahdi M, Hellal H, Griene L, et al. (2002) Expérience de quinze années de lutte contre l'envenimation scorpionique en Algérie. Bull Soc Pathol Exot 95(3): 205-208.

8. Attamo H, Diawara N, Garba A (2002) Epidémiologie des envenimations scorpioniques dans le service de pédiatrie du CHD d'Agadez (Niger) en 1999. Bull Soc Pathol Exot 95: 209-211.

9. APANews (2010) Newletter of 28th September 2010.

10. Wateba I, Baba A, Aziagbe K, Tidjani O (2013) Aspects epidemiologiques, cliniques et therapeutiques des expositions aux morsures suspectes de rage dans le service des maladies infectieuses et de pneumologie du Chu Tokoin de Lome. Journal de la Recherche Scientifique de l'Universite de Lome 13(1).

11. Gogovor K (2005) Données préliminaires sur les morsures de serpents au Togo. Bulletin de la société de pathologie exotique, 98(4): 325-326.

12. Bellefleur J, Le Dantec P (2005) Prise en charge hospitalière des morsures de serpent en Afrique. Bull Soc Pathol Exot 98(4): 273276.

13. Ouro-Bagna K (2009) Contribution à l'étude de la toxicité des plantes médicinales: point de vue du tradithérapeutes, In Secondary "Contribution à l'étude de la toxicité des plantes médicinales: point de vue du tradithérapeutes. Université de Lomé, Togo, p. 40.

14. https://searchworks.stanford.edu/view/9921577
15. Woegan Y (2007) Diversité des formations végétales ligneuses du parc national de Fazao-Malfakassa et de la réserve de faune d'Aledjo (Togo). Acta Botanica Gallica 158(3): 445-449.

16. Dourma M, Batawila K, Guelly KA, Bellefontaine R, Foucault Bd, et al. (2011) Les forêts claires à Isoberlinia doka Craib \& Stapf et I. tomentosa (Harms) Craib \& Stapf (Fabaceae) en zone soudanienne du Togo: écologie, régénération naturelle et activités humaines. Acta Botanica Gallica 158(1): 141-144.

17. MERF (2009) Quatrième rapport national de la convention des nations unies sur la diversité biologiqueTogo. Togo, p. 80.

18. Atakpama W, Kponor GEE, Kanda M, Dourma M, Naré Mt, et al. (2014) Moringa oleifera Lamarck (Moringaceae) : une ressource phytogénétique à usage multiple. Revue CAMES, Sciences de la vie, de la terre et agronomie 2(1): 6-14.

19. Péréki H, Batawila K, Wala K, Dourma M, Akpavi S, et al. (2012) Botanical Assessment of Forest Genetic Resources Used in Traditional Cosmetic in Togo (West Africa). Journal of Life Sciences 6931-938.

20. Hutchinson J, Dalziel J (1954-1972) Flora of west tropical Africa, In Secondary "Flora of west tropical Africa. Crown Publisher, London.

21. Brunel J, Hiepko P, Scholz H (1984) Flore analytique du Togo: Phanérogames. Eschborn GTZ éd., Eschborn, pp. 715.

22. Durecu (2009) Développement de la médecine traditionnelle au Togo: Cas du CERMETRA de la région centrale, In Secondary "Développement de la médecine traditionnelle au Togo: Cas du CERMETRA de la région centrale. Lillle, France. p. 107.

23. Adjanohoun EJ, Ahyi MRA, Ake Assi L, Akpagana K, Chibon K, et al. (1986) Contribution aux études ethnobotaniques et floristiques au TogoAgence de Coopération Culturelle et Technique, Togo, p. 671.

24. Agody K (2007) Contribution au recensement des plantes médicinales au Togo: cas de la région maritime, In Secondary "Contribution au recensement des plantes médicinales au Togo: cas de la région maritime. University de Lomé, Togo. p. 179.

25. Amegan KMG (2012) Contribution au recensement des plantes antianémiques: Cas de la région maritime, In Secondary "Contribution au recensement des plantes antianémiques: Cas de la région maritime. Th. Doc. Pharmacie, Univ. Lomé, Togo, p. 83.

26. Atakpama W, Batawila K, Dourma M, Pereki H, Wala K, et al. (2012) Ethnobotanical knowledge of Sterculia setigera Del. in the Sudanian zone of Togo (West Africa). ISRN Botany, Togo, p. 8.

27. Atakpama W, Batawila K, Gnamkoulamba A, Akpagana K (2015) Quantitative approach of Sterculia setigera Del. (Sterculiaceae) ethnobatanical uses among rural communities in Togo (West Africa). Ethnobotany Research \& Applications 14: 14065-14080.

28. Kébenzikato AB, Wala K, Atakpama W, Dourma M, Woégan YA, et al. (2015) Connaissances ethnobotaniques du baobab (Adansonia digitata L.) au Togo. Biotechnol Agron Soc Environ 19(3): 246-260.

29. Maroyi A, Pieroni A, Gilmore M, Endress B, Horn C, et al. (2013) Traditional use of medicinal plants in south-central Zimbabwe: review and perspectives. J Ethnobiol Ethnomed 9: 31.

30. Hmimou R (2004) Profil épidémiologique des piqûres et des envenimations scorpioniques à l'hôpital provincial d'El Kelaa. In Secondary 'Profil épidémiologique des piqûres et des envenimations scorpioniques à l'hôpital provincial d'El Kelaa. Université Ibn Tofail, Maroc. 